\title{
CSF Study in 101 Cases of Neuro AIDS In Tertiary Hospital
}

\author{
${ }^{1}$ Dr Yelda Puri, ${ }^{2}$ Dr Sadhana Mahore, MD, ${ }^{3}$ Dr Millind Brushundi, MD \\ ${ }^{4}$ Dr Nanji Pal Singh Puri ${ }^{5}$ Dr Malhar Vyas \\ ${ }^{1}$ Junior resident, Department of Pathology ${ }^{2}$ Head and Professor of Department of Pathology \\ ${ }^{3}$ Medical superintendent. ${ }^{4}$ Junior Resident, Department of Medicine \\ ${ }^{5}$ Junior Resident, NKP Salve Institute of Medical Sciences and Research Center. Nagpur. 440019
}

\begin{abstract}
Background: The important causes of death from HIV/AIDS are opportunistic infections and cancers both of which are frequently the result of the progressive failure of the immune system. ${ }^{1,2}$ Tuberculosis co-infection is one of the leading causes of sickness and death in patients of HIV/AIDS and causing 25\% of HIV related deaths. ${ }^{3}$

Hepatitis $C$ is another common co-infection where each disease increases the progression of other disease. ${ }^{4}$ Programmes encouraging the abstinence don't affect the subsequent risk of HIV. ${ }^{5}$ Comprehensive sexual education provided at high school may decrease high risk behaviour. ${ }^{6}$

Up to $70 \%$ of infected individuals have neurological symptoms, and meningitis is the most common cause of HIV related mortality and morbidity in maximum number of patients. ${ }^{7}$ In India according to some of the studies tubercular meningitis is the most common neurological manifestation in HIV patients, followed by Cryptococcus meningitis.

The clinical diagnosis of central nervous system (CNS) diseases in patients with AIDS is based on neurological examination and Neuro imaging studies. Further examinations, such as standard analysis of cerebrospinal fluid (CSF) may be useful. The diagnosis of pathogen in the CSF or brain makes a diagnosis of etiology possible.

Hence, the present study was undertaken to evaluate the CSF of patients suspected of Neuro AIDS.
\end{abstract}

\section{Material And Methods}

This was a hospital based cross sectional study, conducted for a period of 2 years. Total of 101 cases were studied. All HIV positive patients with neurological signs and symptoms irrespective of age and sex or whether receiving or not receiving ART were included in this study. CSF tap of these patients were done. The study was carried out in the department of pathology. HIV positive patient without neurological signs and symptoms were not included in this study

\section{Methods of Collection Of Data}

A detailed history of patients like age, sex, address, family history, mode of transmission, treatment history andhistory of coexisting illness were taken and entered in proforma. Following tests were done by the physician to diagnose HIV positive patient with neurological complications ie:

- ELISA/Tridott/Abott

- CD4+ count

- VDRL

- HBSAg

- $\mathrm{CT} / \mathrm{MRI}$

CSF tap from diagnosed Neuro AIDS patients was done by lumber puncture under all aseptic precautions and sent for study in pathology department.

Once the CSF received, it was reported under following headings:

- Gross appearance, Cell count, Biochemistry( Sugar, Proteins), Stains (Gram stain, AFB and India ink)

\section{Reporting Of CSF}

Gross appearance of CSF was reported accordingly. As it varies in different conditions. Direct wet mount of CSF was taken for microscopic examination. One drop of CSF after centrifugation was taken directly on a glass slide covered with a cover glass, and was examined under the microscope.

\section{Cell Count in CSF}

TLC

Cell count on CSF was done manually on undiluted sample on a counting chamber

Procedure 
CSF sample was properly mixed and the counting chamber was covered with a cover slip. The counting chamber was filled with a fluid and allowed to stand for 2 minutes for the cells to settle down. Fuchs Rosenthal counting chamber was used for counting the cells in CSF. In case of undiluted CSF, total number of cells counted in 5 squares represented the total count per $\mathrm{mm}^{3}$ of CSF.

\section{DLC}

It provided with the information of relative proportion of various leukocytes. If the CSF contained few cells then it was centrifuged at high speed for 10 minutes and a smear was made from the sediment. If CSF contained many cells, then a smear was made directly from the uncentrifuged sample, stained with the romanowsky stain (Leishman stain), and examined under the microscope.

\section{Chemical Examination Of CSF}

The routine examination of CSF for sugar was carried out in biochemistry laboratory with the help of VITA LAB - Selectra E machine and CSF proteins was carried out with the help of prietest Micro Protein reagent on photometric system in biochemistry laboratory. AFB, gram staining and culture was also performed on CSF to look for Mycobacterium tuberculosis. The culture reports were collected from the microbiology department.

Tubercular meningitis was diagnosed on the basis of existing criteria. ${ }^{8}$

- Definite- demonstration of M. tuberculosis (AFB) in CSF.

- Highly probable- M. tuberculosis not demonsrated in the CSF but

- CSF findings compatible with TBM ie proteins $>0.60 \mathrm{~g} / \mathrm{l}$, sugar $<60 \%$ of corresponding blood sugar and $>20$ cells $/ \mathrm{mm}^{3}$ with lymphocytic predominance.

- Evidence of extra central nervous system (CNS) tuberculosis.

- Exclusion of other etiologies of meningitis and

- Positive response to anti-tuberculous therapy.

- Probable- M.tuberculosis not demonstrated but features 1, 3 and 4 present.

Cryptococcal meningitis was diagnosed on the basis of CSF findings and positive India ink. Patients having normal CSF findings were diagnosed on the basis of their CT/MRI reports.

Patients having features suggestive of toxoplasmosis, PML, cerebral oedema or cerebral atrophy were diagnosed as such on the basis of their findings.

\section{Methods Of Statistical Analysis}

Statistical software Epi info software (3.4.3 version) was used for data analysis.

Coefficient of correlation was calculated to determine correlation between CD4 count and WHO staging.

\section{Ethical Requirements}

Patients were informed about the study and a written consent was taken from the patients prior to the procedure. The consent was taken on a specified consent form.

\section{Results}

In the present study 73 cases $(72.27 \%)$ belonging to age group 30-49 years were affected, followed by 15-29 years of age group. 81 cases $(80.19 \%)$ of males were affected, followed by 20 cases (19.80\%) of females. 47 cases $(46.53 \%)$ were on treatment, 35 cases $(34.65 \%)$ were not on treatment and 19 cases $(18.81 \%)$ were on interrupted treatment. 81 cases had HIV partners as mode of transmission of virus while 11 cases didn't know the source of infection. Headache was the most common neurological symptom seen in 81 cases $(80.19 \%)$, followed by seizures in 24 cases $(23.76 \%)$ and behavior changes in 16 cases $(15.84 \%) .80$ cases $(79.20 \%)$ were of WHO stage 4 and 21 cases (20.79\%) of stage 3.81 cases (80.19\%) had CD4 count $<200 / \mathrm{mm}^{3}$ and 20 cases

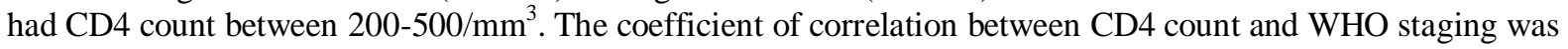
0.84 .

Table: 1.1 CSF findings in Neuro AIDS patients

\begin{tabular}{|l|c|c|}
\hline CSF finding & No. of patients & Percentage \\
\hline PROTEIN & 64 & $63.36 \%$ \\
HIGH & 37 & $36.63 \%$ \\
NORMAL & 53 & \\
\hline SUGAR & $52.47 \%$ \\
LOW & 48 & $47.52 \%$ \\
NORMAL & & \\
\hline CELL & 55 & $54.45 \%$ \\
COUNT/MM & & $45.54 \%$ \\
HIGH & 46 & \\
NORMAL & & \\
\hline
\end{tabular}




\begin{tabular}{|l|c|c|}
\hline DLC & & \\
LYMPHOCYTOSIS & 51 OUT OF 55 & $92.72 \%$ \\
NEUTROPHILIA & 04 OUT OF 55 & $7.27 \%$ \\
\hline AFB & 01 & $0.99 \%$ \\
POSITIVE & 100 & $99 \%$ \\
NEGATIVE & 1 positive & $0.99 \%$ \\
\hline GRAM STAIN & 14 & $13.86 \%$ \\
\hline INDIA INK & 02 & $1.98 \%$ \\
CRYPTO & 85 & $83.16 \%$ \\
CANDIDA & & \\
Negative & & \\
\hline
\end{tabular}

36 patients (35.64\%) showed positive CTs findings and 6 patients (5.94\%) showed MRI findings. Final diagnosis on basis of CSF and CT/MRI findings were given as: TBM in 32 cases (31.68\%), viral encephalitis in 15 cases $(14.85 \%)$, cryptococcal meningitis in 14 cases $(13.86 \%) .4$ cases of TBM had hydrocephalus. PML was the least common manifestation seen in 1 case $(0.99 \%)$ only.

\section{Discussion}

In the present study $80.19 \%$ of patients were male and $19.80 \%$ females. $72.27 \%$ of patients belonged to $30-49 \mathrm{yrs}$ of age group, as this age group is sexually more active while $18.81 \%$ were between $15-29 \mathrm{yrs}$ of age. This is in concordance with the study conducted by Rangnathan $\mathrm{et}^{\mathrm{9}}{ }^{9}$ in 2004 . Male: female ratio was 4:1 in the present study. While Sonkar SK et a ${ }^{10}$ reported M:F ratio as 4:1. In India, males are the bread earners and most of them harbour the disease from commercial sex workers. Present study reported $46.53 \%$ (47patients) taking treatment, $35.67 \%$ patients (35 patients) not on treatment and remaining $18.81 \%$ patients taking interrupted treatment. After initiation of ART, opportunistic infections (OI) and other HIV-related events still occur secondary to a delayed recovery of adequate immunity. ${ }^{11}$

Fig 1.2 Comparison of various Neurological symptoms with different studies:

\begin{tabular}{|c|c|c|c|c|}
\hline Symptoms & $\begin{array}{l}\text { Sonkar et } \mathrm{al}^{10} \\
2012\end{array}$ & $\begin{array}{l}\text { Bolokadze } \mathrm{N} \text { et } \mathrm{al}^{12} \\
2008\end{array}$ & Pal et $\mathrm{al}^{13}$ & $\begin{array}{l}\text { Present study } \\
2014(n=101)\end{array}$ \\
\hline Headache & $67.4 \%$ & $91 \%$ & - & $81.18 \%$ \\
\hline Seizures & $14 \%$ & $15 \%$ & $33 \%$ & $23.76 \%$ \\
\hline Behaviour change & - & $41 \%$ (cognitive dysfunction) & - & $15.84 \%$ \\
\hline
\end{tabular}

The difference in the percentage of patients having behaviour change can be due to the sample size taken, as the study conducted by Bolokadze $\mathrm{N}$ et al ${ }^{12}$ had 388 patients while our study had 101 patients. In the present study 81 cases $\left(80.19 \%\right.$ ) had CD4 count less than $200 / \mathrm{mm}^{3}$. This correlates with the findings of other studies done by Sharma SK et al ${ }^{14}$, Likittanasombut $\mathrm{P}$ et al ${ }^{15}$ and Sonkar SK et al. ${ }^{10}$ They reported $82.6 \%, 96 \%$ and $63.2 \%$ patients with less than $200 / \mathrm{mm}^{3} \mathrm{CD} 4$ count respectively.

20 cases $(19.80 \%)$ were reported with CD4 count between $200 / \mathrm{mm}^{3}$ to $500 / \mathrm{mm}^{3}$ in the present study. Patients having CD4 count between $200 / \mathrm{mm}^{3}$ to $500 / \mathrm{mm}^{3}, 14$ patients were of tubercular meningitis (TBM), 2 patients were of pyogenic meningitis (PM), 1 of fungal meningitis (FM) and 3 were undiagnosed. This correlates with the study conducted in Melbourne by Crowe S M et al. ${ }^{16}$ They reported that, tuberculosis and oropharyngeal candidiasis develop when CD4 count is in range of $250-500 / \mathrm{mm}^{3}$. When the CD4 count decline to approximately $100 / \mathrm{mm}^{3}$, the common AIDS defining OIs develop, such as toxoplasmosis, cryptococcal meningitis etc. Patients were classified into different HIV stages using WHO staging system. 80 cases $(79.20 \%)$ in the present study belong to WHO stage 4 while remaining 21 cases $(20.79 \%)$ belong to stage 3 . This was an expected finding as this study was carried on Neuro AIDS patients. An attempt was made to see the correlation between CD4 count and WHO staging which co-related well with coefficient of correlation of 0.84 but 2 cases had CD4 count less than $200 / \mathrm{mm}^{3}$ and which belonged to WHO stage 3. 1 case was diagnosed as TBM and 1 was undiagnosed. Edathodu $\mathrm{J}$ et $\mathrm{al}^{17}$ found 20 patients in stage 3 with CD4 count less than $200 / \mathrm{mm}^{3}$ and coefficient of correlation of -0.65 .

Fig 1.3 Comparison of various percentages of neurological manifestations diagnosed on basis of CSF findings and/or CT/MRI with different studies.

\begin{tabular}{|c|c|c|c|c|c|c|c|c|}
\hline Findings & $\begin{array}{l}\text { Singh R } \\
\text { et }^{1} l^{18}\end{array}$ & $\begin{array}{l}\text { Sharma } \\
{\text { SK et } \text { al }^{14}}\end{array}$ & $\begin{array}{c}\text { Sonkar } \\
\mathrm{S} \mathrm{K} \\
\text { etal }^{10}\end{array}$ & $\begin{array}{l}\text { S.Chandra } \\
\text { et al }^{19}\end{array}$ & $\begin{array}{c}\text { Lewy et } \\
\mathrm{al}^{20}\end{array}$ & $\begin{array}{l}\text { Bolokadze } \\
\text { et }^{12}{ }^{12}\end{array}$ & 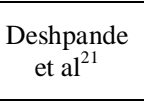 & $\begin{array}{l}\text { Present } \\
\text { study }\end{array}$ \\
\hline TB/TBM & $14.18 \%$ & $71.1 \%$ & $70.0 \%$ & $34 \%$ & 0 & $34 \%$ & $8 \%$ & $31.68 \%$ \\
\hline $\mathrm{CM}$ & $6.01 \%$ & $3.7 \%$ & $23.3 \%$ & $37 \%$ & $5.03 \%$ & $15 \%$ & $17 \%$ & $13.88 \%$ \\
\hline Pyogenic meningitis & -- & -- & -- & -- & -- & -- & $4 \%$ & $3.9 \%$ \\
\hline Fungal meningitis & -- & -- & -- & -- & -- & -- & -- & $1.9 \%$ \\
\hline Viral encephalitis & -- & -- & $4.66 \%$ & -- & -- & -- & -- & $14.85 \%$ \\
\hline
\end{tabular}


CSF study in 101 cases of Neuro AIDS in tertiary hospital

\begin{tabular}{|c|c|c|c|c|c|c|c|c|}
\hline Toxoplasmosis & $0.72 \%$ & $3.7 \%$ & & $13 \%$ & $5.66 \%$ & $22 \%$ & $20.33 \%$ & $4.9 \%$ \\
\hline HAD & $33.60 \%$ & -- & $9.30 \%$ & $5 \%$ & -- & $2.40 \%$ & $1.33 \%$ & $3.9 \%$ \\
\hline Infarct & & & & & & & & $1.98 \%$ \\
\hline Hydrocephalus & & & & & & & & $2.95 \%$ \\
\hline $\begin{array}{c}\text { Cerebeller } \\
\text { demylination }\end{array}$ & -- & -- & $4.66 \%$ & -- & -- & --- & -- & $1.98 \%$ \\
\hline Cerebral atrophy & & & & & & & & $3.9 \%$ \\
\hline Cerebritis & -- & -- & -- & -- & -- & -- & -- & $3.9 \%$ \\
\hline SOL & 1.44 & - & $6.98 \%$ & $8 \%$ & $3.46 \%$ & $10.7 \%$ & $21 \%$ & $2.97 \%$ \\
\hline PML & $0.72 \%$ & $0.7 \%$ & & $1 \%$ & $0.63 \%$ & $5 \%$ & $6.67 \%$ & $0.99 \%$ \\
\hline Lymphoma & & $1.5 \%$ & & & & & $5 \%$ & \\
\hline Undiagnosed & -- & -- & -- & -- & -- & -- & --- & $5.94 \%$ \\
\hline Total & & & & & & & & $100 \%$ \\
\hline
\end{tabular}

Attili SVS 22 et al has reported TBM in $25.1 \%$ patients and CM in $11.0 \%$ of cases.

15 cases $(14.85 \%)$ had viral encephalitis in the present study. It occurs in $15-40 \%$ cases of HIV, though no systemic studies are available. ${ }^{23} 6$ patients were classified under undiagnosed category as they complained of single episode of seizure, with normal CSF and CT/MRI findings.

All the patients had undergone CSF tap in the present study and CSF abnormalities were seen in 81 patients. 86.13\% (87 cases) had clear CSF. 1 patient of TBM had cob web formation and 13 patients had turbid CSF out which 8 patients were of TBM. Out of 101 cases 64 cases (63.36\%) had increase protein while 55 cases (54.45\%) had pleocytosis. CSF sugar was low in 53 cases (52.47).

32 cases (31.68\%) showed features suggestive of TBM (tubercular meningitis), 7 cases $(8.91 \%)$ were diagnosed with viral encephalitis by their CSF findings, 1 case had both CSF and CT/MRI findings and remaining 6 cases were diagnosed purely on CT/MRI. 14 cases (13.86\%) had cryptococccal meningitis, 4 cases (3.9\%) had pyogenic meningitis and 2 cases (1.9\%) had fungal meningitis.

Fig: 1.4 CSF comparison of Tuberculous meningitis patients with other studies.

\begin{tabular}{|c|c|c|c|}
\hline TBM & $\begin{array}{c}\text { Thwaites G.E et al } \\
24\end{array}$ & $\begin{array}{c}\text { Cecchini D et al } \\
2009\end{array}$ & $\begin{array}{c}\text { Present study } \\
2014\end{array}$ \\
\hline CSF sugar $\mathrm{mg} / \mathrm{dl}$ & - & $28(20-42)$ & $29.5(10-56)$ \\
\hline CSF proteins g/L & - & $0.77(0.37-1.45)$ & $0.85(0.32-1.40)$ \\
\hline CSF cells $/ \mathrm{mm}^{3}$ & $152(34-430)$ & $47(6-252)$ & $100(30-470)$ \\
\hline
\end{tabular}

Values are median (range)

Fig: 1.5 CSF comparison of TBM patients with other study

\begin{tabular}{|c|c|c|c|}
\hline TBM & Katrak et al $^{10} 2000$ & Present study 2014 & TBM \\
\hline CSF Sugar g/l & $0.46 \pm 0.21$ & $0.31 \pm 0.11$ & \multirow{2}{*}{ CSF Sugar g/l Range } \\
Range & $0.25-1.00$ & $0.1-0.56$ & CSF Proteins g/l \\
\hline CSF Proteins g/l & $1.24 \pm 0.88$ & $1.1 \pm 0.57$ & Range \\
Range & $0.45-3.26$ & $0.32-2.68$ & CSF cells $/ \mathrm{mm}^{3}$ \\
\hline CSF cells $/ \mathrm{mm}^{3}$ & $146 \pm 139$ & $147 \pm 129$ & Range \\
Range & $36-550$ & $30-470$ & \\
\hline
\end{tabular}

Values are mean.

Studies done by Bergemann A et al, ${ }^{26}$ Bekondi $\mathrm{C}$ et $\mathrm{al}^{27}$ and Likkittanasombut $\mathrm{P}$ at $\mathrm{al}^{15}$ reported inflammatory CSF (increased protein, low sugar and pleocytosis in range of $0-2340 \times 10^{9} / 1$ ) in TBM patients. HIV infected individuals with TBM may therefore have a non inflammatory CSF characterstics. ${ }^{25,28}$ In such cases, diagnosis of TBM cannot be excluded on the basis of normal CSF cell count. A high level of suspicion is necessary. ${ }^{25}$ In the majority of studies TBM diagnosis is presumptive and based on a combination of clinical, laboratory and radiological findings, emphasising the need for development of a standardized case definition. ${ }^{29}$

In the present study, CSF cells ranged varied from $30 / \mathrm{mm}^{3}$ to $470 / \mathrm{mm}^{3}$ and CSF protein was markedly low, as seen in above mentioned studies, hence CSF cells and protein of TBM patients may have a varied range, and lower CSF cell count and protein values doesn't rule out TBM.

In the present study one patient stained positive with AFB (acid fast bacilli) as the yield for acid fast bacilli on CSF is low. ${ }^{30}$

CSF culture for M. tuberculosis was positive in 5 patients (15.6\%). This could be due to the fact that CSF protein concentration was less in the present study and absence of neutrophils in remaining cases. High protein CSF concentration and large proportion of CSF neutrophils in CSF (markers of the acute phase), are associated to higher bacteremia, leading to positive cultures. ${ }^{31}$

In the present study 14 cases (13.86\%) were diagnosed with Cryptococcal meningitis on the basis of clinical findings and CSF India ink preparation. All the cases of cryptococcal meningitis were positive on India ink. 
One patient's CSF was gram positive for diplococci (streptococci pneumonie). The poor yield of Gram stain and culture, could be due the fact that these cases were on antibiotic treatment before hospital admission. ${ }^{27}$

35 cases (34.64\%) showed CT findings and 6 cases (5.9\%) had MRI findings ( 3 cases of encephalitis, 1 case of cerebritis, 1 case of tuberculoma and 1 case of hydrocephalus).

In conclusion, from present study and other studies conducted on CSF, it shows that lymphocytic range varies markedly as well as rate of culture positivity and AFB demonstration on CSF was also low, so high index of suspicion is necessary to confirm or to rule out tuberculosis. More advanced test like PCR should also be done on CSF. Though routine CSF examination is the first line of investigation, it is easy and cost effective method, but more additional tests should also be conducted, where CSF is inconclusive.

\section{References}

[1]. Smith BT, James CW, Sabundaya BP. Immunology of HIV infection and AIDS. In: Concepts in immunology and immunotherapeutic. $4^{\text {th }}$ ed. American society of health system pharmacist; 2008:143.

[2]. Cheung MC, Pantanowitz L, Dezube BJ. AIDS-related malignancies: emerging challenges in the era of highly active antiretroviral therapy. Oncologist. 2005 Jun-Jul;10(6):412-26.

[3]. Park K. Epidemiology of communicable diseases. In: Park's Textbook Of Preventive and Social Medicine. 22 ${ }^{\text {nd }}$ edition. Banarsidas Bhanot publishers; 2013:316-327.

[4]. Warren JS, Strayer DS. Immunopathology. In: Rubin S, Strayer DS editors. Rubin Pathology. $6^{\text {th }}$ edition. Lippincott Williams \& Wilkins; 2012:154.

[5]. Underhill K, Montgomery P, Operario D. Abstinence-plus programs for HIV infection prevention in high income countries. Cochrane Database Syst Rev. 2008 Jan 23;(1):CD007006.

[6]. Ljubojevic S, Lipozencic J. Sexually transmitted infection and adolescence. Acta Dermatovenerol Croat. 2010;18(4):305-10.

[7]. Wadia RS, Pujari SN, Kothari S, Udhar M, Kulkarni S, Bhagat S et al. Neurological manifestations of HIV disease. J Assoc Physicians India. 2001 Mar;49:343-8.

[8]. Katrak SM, Shembalkar PK, Bijwe SR, Bhandarkar LD. The clinical, radiological and pathological profile of tuberculous meningitis in patients with and without human immunodeficiency virus infection. J Neurol Sci. 2000 Dec 1;181(1-2):118-26.

[9]. Ranganathan K, Umadevi M, Saraswathi TR, Kumarasamy N, Solomon S, Johnson N et al. Oral lesions and conditions associated with human immunodefeciency virus infection in 1000 South Indian patients. Ann Acad Med Singapore. 2004Jul;33(4 suppl):3742.

[10]. Sonkar SK, Gupta A, Atam V, Chaudhary SC, Tripathi AK, Sonkar GK. Clinical Profile of Neurological Manifestation in Human Immunodeficiency Virus-positive Patients. N Am J Med Sci. 2012 Nov;4(11):596-9.

[11]. Ledergerber B, Egger M, Erard V, Weber R, Hirschel B, Furrer H et al. AIDS-related opportunistic illnesses occurring after initiation of potent antiretroviral therapy: the Swiss HIV Cohort Study. Jama. 1999 Dec 15;282(23):2220-6.

[12]. Bolokadze N, Gabunia P, Ezugbaia M, Gatserelia L, Khechiashvili G. Neurological complications in patients with HIV AIDS. Georgian Med News. 2008 Dec;(165):34-8.

[13]. Pal J, Karmakar PS, Ray A, Saha S, Roy K, Talukdar A et al. Opportunistic infections of central nervous system in AIDS. J Indian Med Assoc.2009 Jul;107(7):446-9.

[14]. Sharma SK, Kadhiravan T, Banga A, GOYAL T, Bhatia I, Saha PK. Spectrum of clinical disease in a series of 135 hospitalized HIV-infected patients from north India. BMC Infect Dis. 2004 Nov 22; 4:52.

[15]. Likittanasombut P. Opportunistic central nervous system infection in human immunodeficiency virus infected patients in Thammasat Hospital, Thailand. Neurology Asia 2004;9:29-32.

[16]. Crowe SM, Carlin JB, Stewart KL, Lucas CR, Hoy JF. Predictive value of CD4 lymphocyte numbers for the development of opportunistic infections and malignancies in HIV infected persons. J Acquir Immune Defic Syndr.1991;4(8):770-6.

[17]. Edathodu J, Ali B, Alrajhi AA, CD4 validation for the World Health Organization classification and clinical staging of HIV/AIDS in a developing country. Int J Infect Dis. 2009 Mar;13(2):243-6.

[18]. Singh R, Kaur M, Arora D. Neurological complications in late stage hospitalized patients with HIV disease. Ann Indian Acad Neurol. 2011 Jul;14(3):172-7.

[19]. Satishchandra P, Nalini A, Gourie-Devi M, Khanna N, Santosh V, Ravi V, et al. Profile of neurologic disorders associated with HIV/AIDS from Bangalore, South India (1989-1996). Indian J Med Res. 2000 Jan;111: 14-23.

[20]. Levy RM, Bredesen DE, Rosenblum ML. Neurological manifestations of the acquired immunodeficiency syndrome (AIDS): experience at UCSF and review of the literature. J Neurosurg. 1985 Apr;62(4):475-95.

[21]. Deshpande AK, Patnaik MM. Nonoppurtunistic neurologic manifestation of the human immunodeficiency virus: an Indian study. MedGenMed. 2005 Oct 4;7(4):2.

[22]. Attili SVS, Gulati VK, Singh VP, Varma DV, Rai M, Sundar S. Diarrhea, CD4 counts and enteric infections in a hospital- based cohort of HIV-infected patients around Varanasi, India. BMC Infect Dis. 2006 March;6:39.

[23]. Berger JR, Kaszovitz B, Post MJ, Dickinson G. Progressive multifocal leukoencephalopathy associated with human immunodeficiency virus infection. A review of literature with a report of sixteen cases. Ann Intern Med. 1987 Jul;107(1):78-87.

[24]. Thwaites GE, Chau TT, Caws M, Phu NH, Choung LV, Sinh DX et al. Isoniazid resistance, mycobacterial genotype and outcome in Vietnamese adults with tuberculous meningitis. Int J Tuberc Lung Dis. 2002 Oct;6(10):865-71.

[25]. Cecchini D, Ambrosioni J, Brezzo C, Corti M, Rybko A, Perez M et al. Tuberculous meningitis in HIV-infected and non-infected patients: comparison of cerebrospinal fluid findings. Int J Tuberc Lung Dis. 2009 Feb;13(2):269-71.

[26]. Bergemann A, Karstaedt AS. The spectrum of meningitis in a population with high prevalence of HIV disease. QJM. 1996 Jul;89(7):499-504.

[27]. Bekondi C, Bernede C, Passone N, Minssart P, Kamalo C, Mbolidi D et al. Primary and opportunistic pathogens associated with meningitis in adults in Bangui, Central African Republic, in relation to human immunodeficiency virus serostatus. Int J Infect Dis. 2006 Sep;10(5):387-95.

[28]. Lanjewar DN, Jain PP, Shetty CR. Profile of central nervous system pathology in patients with AIDS: an autopsy study from India. AIDS 1998 Feb 12;12(3):309-13.

[29]. Shankar SK, Mahadevan A, Satishchandra P, Kumar RU, Yasha TC, Santosh V, et al. Neuropathology of HIV/AIDS with an overview of the Indian scene. Indian J Med Res. 2005 Apr;121(4):468-88.

[30]. Kumar R, Singh SN, Kohli N. A diagnostic rule for tuberculosis meningitis. Arch Dis Child. 1999 Sep;81(3):221-224. 
[31]. Puccioni-Sohler M, Brandao CO. Factors associated to the positive cerebrospinal fluid culture in tuberculous meningitis. Arq Neuropsiquiatr. 2007 Mar;65(1):48-53.

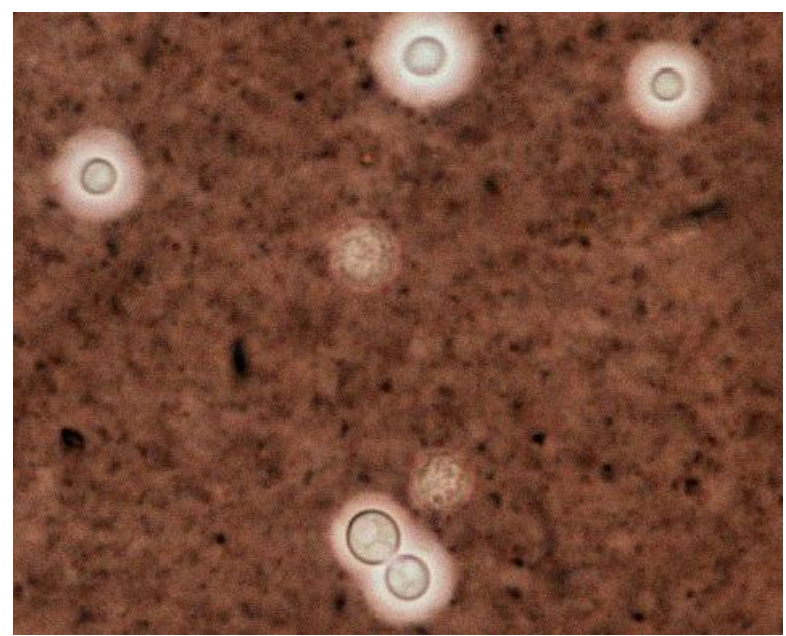

Fig 1 cryptococcus in CSF India ink preparation. (1000x)

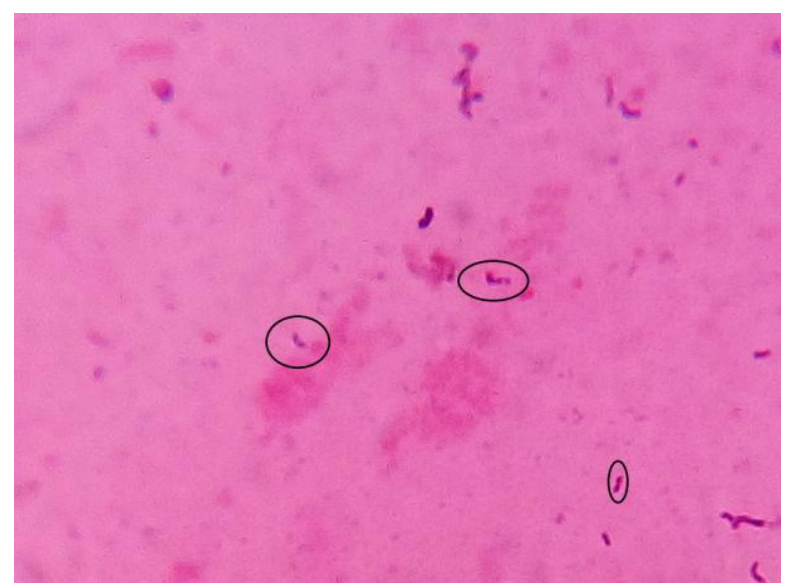

Fig 2 pneumococcus in chain and rods in CSF . Gram stain (1000X)

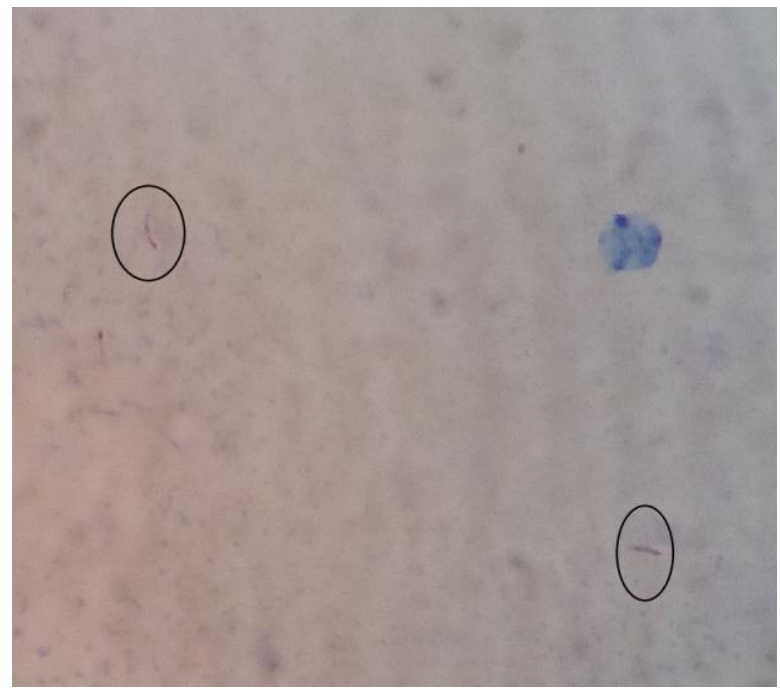

Fig 3: Mycobacterium tuberculosis positive on AFB in CSF. (1000x) 